\title{
Uključenost u fizioterapiju i tjelesne aktivnosti osoba s mijastenijom gravis
}

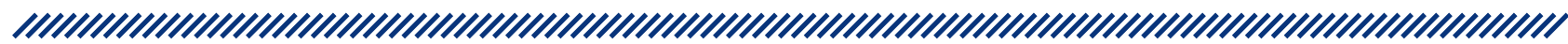

1 Marija Marinović

1 Mirjana Telebuh

2 Iva Lončarić Kelečić

1 Gordana Grozdek Čovčić

3 Želimir Bertić

1 Mihaela Grubišić

1 Zdravstveno veleučilište Zagreb

2 Klinički zavod za rehabilitaciju i ortopedska pomagala, KBC Zagreb

3 Zavod za javno zdravstvo Bjelovarsko-bilogorske županije tra kako planirana tjelesna aktivnost pogoršava njihovo zdravstveno stanje, nema utjecaja ili nisu upoznati s učincima na zdravstveno stanje, manje su tjelesno aktivne i većinski nisu uključene u proces fizioterapije ni u neki drugi vid tjelesne aktivnosti. Statistički značajna razlika funkcioniranja u svakodnevnom životu nađena je kod osoba koje su operirale timus $(p<0,00)$ i koje imaju problema s inkontinencijom $(p<0,00)$. Neupitno je da mijastenija gravis dovodi do smanjenja funkcioniranja u svakodnevnom životu te da edukacija oboljelih o važnosti terapijskog vježbanja donosi benefite u smislu boljeg funkcioniranja za oboljele od mijastenije gravis.

Ključne riječi: mijastenija gravis, fizioterapija, terapijske vježbe, inkontinencija, funkcioniranje u svakodnevnom životu

Datum primitka: 07. 12. 2020.

Datum prihvaćanja: 15.01.2021.

https://doi.org/10.24141/1/7/1/4

Adresa za dopisivanje:

Mirjana Telebuh

A: Zdravstveno veleučilište Zagreb, Mlinarska 38, 10000 Zagreb

E-pošta: mtelebuh@zvu.hr

T: +385914595738 


\section{Uvod}

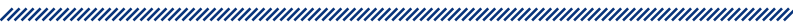

Mijastenija gravis jest autoimuna neuromuskularna bolest i najčešći primarni poremećaj neuromuskularne spojnice. ${ }^{1,2}$ Mijastenija gravis kronična je i progresivna bolest obilježena oscilirajućim slabostima skeletnih mišića zbog stvaranja protutijela protiv acetilkolinskih receptora u neuromuskularnim sinapsama, ${ }^{3}$ odnosno organizam stvara protutijela protiv receptora na mišićnim stanicama i tako sprječava i remeti prijenos podražaja sa živaca na mišiće. Prvi poznati slučaj opisan je kod američkog domorodca poglavice Opechancanough, koji je umro 1664. godine. U spisima se navodi kako je poglavica bio toliko slab da nije mogao hodati, što je zahtijevalo da ga se nosi na nosilu. Vjeđe su bile tako slabe da su ih morali podizati njegovi pratitelji, ali zapaženo je i poboljšanje slabosti nakon odmora. ${ }^{4}$ Bolest prvi put 1672 . anatom Thomas Willis opisuje kao „lažnu paralizu”. Friedrich Jolly 1895. prvi zapaža reakciju mišića na faradsku struju koja uzrokuje jaki zamor i to naziva „mijasteničnom reakcijom", uvodi termin myasthenia gravis pseudoparalitica, a danas se upotrebljavaju samo prve dvije riječi. ${ }^{5}$ Prevalencija mijastenije gravis u svijetu, kako pokazuju studije, u rasponu je od 70 do 400 na 1000000 osoba, s incidencijom od 10 do 20 na 1000000 osoba. Incidencija je najčešća oko dvadesete i tridesete godine. U mlađoj dobi češće se javlja kod žena, dok je u starijoj dobi podjednaka. Globalno gledano žene obolijevaju tri puta češće od muškaraca. ${ }^{6}$ Mijastenija gravis klasificira se modificiranom Ossermanovom podjelom (1971), a definirala ju je Američka zaklada za mijasteniju gravis (Myasthenia Gravis Foundation of America - MGFA). Prema MGFA-u, mijastenija gravis dijeli se na: I. - isključivo očna simptomatologija; Il.a - blaga slabost uglavnom mišića trupa i udova; II.b - blaga slabost uglavnom bulbarne ili/i respiratorne muskulature; III.a - umjerena slabost, uglavnom mišića trupa i udova; III.b - umjerena slabost, uglavnom bulbarne ili/i respiratorne muskulature; IV.a - teška slabost, uglavnom mišića trupa i udova; IV.b - teška slabost, uglavnom bulbarne ili/i respiratorne muskulature i V. intubacija. ${ }^{6}$

Mijastenija gravis klinički se očituje izraženim mišićnim umorom te slabošću mišića. Tipično je za ovu bolest da slabost oscilira tijekom dana pa je snaga ujutro bolja, a u večernjim satima manja; odnosno simptomi su nakon odmora manji, a pojačavaju se kod napora. ${ }^{7}$ Oko $15 \%$ osoba oboljelih od mijastenije gravis ima tumor timusa, timom, ${ }^{6}$ dok je abnormalnost timusa prisutna u $80 \%$ bolesnika. ${ }^{2}$ Rezultati istraživanja Congregadoa i suradnika (2017) pokazuju kako timektomija može poboljšati kvalitetu života u svim aspektima (tjelesna funkcija, tjelesna uloga, emocionalna uloga, bolovi u tijelu, sveukupno zdravlje, vitalnost, socijalne funkcije i mentalno zdravlje). ${ }^{8}$ Distribucija je zahvaćenih mišića individualna, kao i simptomi. Dvije trećine bolesnika inicijalno se javlja zbog spuštanja vjeđe i dvoslika, a $10 \%$ zbog slabosti mišića ekstremiteta. ${ }^{2}$ Okularni su simptomi ptoza, diplopije i slabost mišića koji pokreću očne jabučice. Osobe koje imaju okularne simptome često pri hodu radi spuštenih vjeđa jače podignu glavu i odignu obrve. Bulbarni su simptomi dizartrija, disfonija, nazalni govor, disfagija, smetnje žvakanja, gutanja i hipomimija. ${ }^{9}$ Slabost stiska šake manje je zahvaćena, dok su jače zahvaćene ekstenzija prstiju i šaka i ekstenzija stopala. Osobe oboljele od mijastenije gravis kod slabosti mišića ramena i ruku imaju poteškoće kod oblačenja, umivanja, tuširanja, češljanja, sušenja kose i brijanja. Zbog slabosti natkoljeničnih i zdjeličnih mišića dolazi do otežanog hoda, ustajanja, gegavog hoda te smanjene pokretljivosti. ${ }^{10}$ Slabost vratnih mišića otežava uspravno držanje glave (engl. head drop), osobe se žale na bol u vratu radi primarne slabosti nuhalnih mišića. ${ }^{11}$ Slabost dišnih mišića dovodi do respiratorne insuficijencije. Otežano je smijanje, fućkanje (funkcionalno poteškoće pri oralnoj higijeni) i ekspresija emocija. Slabost mišića ždrijela i jezika uzrokuje poteškoće gutanja odnosno hranjenja, u periodima kada bolesnik ne može gutati hrani se infuzijom ili se postavlja nazogastrična sonda. Nakon 15 do 20 godina mišićna slabost postaje fiksna te je kod najteže zahvaćenih mišića reducirana mišićna masa. ${ }^{6}$

Mijastenična kriza životno je ugrožavajuća komplikacija mijastenije gravis. $15 \%$ do $20 \%$ bolesnika tijekom života doživi mijasteničnu krizu, a najčešće se javlja tijekom prve dvije godine bolesti. Smrtnost je pala s $40 \%$ 1969. na $5 \% 1970$. godine zbog poboljšanja u respiratornoj njezi i upravljanju jedinica intenzivne njege te pojave specijaliziranih odjela neurointenzivne njege i široke primjenom imunoterapije. ${ }^{12}$ Sustavne bolesti, posebice virusne respiratorne infekcije, emocionalni stres, hipotiroidizam ili hipertiroidizam, neki lijekovi, vruća voda, trudnoća i menstrualni ciklus mogu uzrokovati egzacerbaciju mijastenije gravis, a u najgorem slučaju dovesti do mijasteničnih kriza čiji je vodeći znak respiratorna insuficijencija kao posljedica zatajenja dišne muskulature. ${ }^{13}$ Pneumonija, infekcije i operacije mogu dovesti do mijastenične krize. ${ }^{14}$ Kod pacijenata $s$ pozitivnim anti-AchR antitijelima prvi slabe međurebreni i pomoćni dišni mišići, a zatim ošit, dok u MuSK pozitivnom obliku mijastenije gravis 
zatajenju disanja prethodi slabost bulbarne muskulature. ${ }^{15}$ Kriza se može prepoznati po respiratornoj slabosti, otežanom disanju i disanju s pomoću pomoćne muskulature. Primjenjuje se mehanička ventilacija, no ako je potrebno, provodi se invazivna metoda intubacije.

Sa smanjenjem funkcija na tjelesnoj, socijalnoj, radnoj i emocionalnoj razini mijastenija gravis uzrokuje postupno smanjenje kvalitete života. ${ }^{8}$ Kulkantrakorn i Jarungkiatkul (2010) navode kako mijastenija gravis ima znatan utjecaj na neovisnost, samopouzdanje i radnu sposobnost. ${ }^{16}$ Hrvatsko istraživanje čiji je cilj bio ispitivanje kvalitete života osoba s mijastenijom gravis pokazalo je da polovina ispitanika nije zadovoljna svojom kvalitetom života. Utjecaj mijastenije gravis na radnu sposobnost pokazao je slične rezultate. ${ }^{17}$ Upoznavanje okoline bolesnika s problemima koje nosi mijastenija gravis moglo bi doprinijeti poboljšanju kvalitete života s obzirom na to da su istraživanja pokazala bolju kvalitetu života kod oboljelih koji imaju potporu okoline. Edukacija šire javnosti mogla bi spriječiti predrasude prema oboljelima, pogotovo u radnom okruženju. ${ }^{18}$

Kontinuirano provođenje terapijskih vježbi najvažnije je u održavanju mišićne snage te funkcionalnosti bolesnika. Ciljevi su fizioterapijskog programa ublažavanje ili sprječavanje smanjenja funkcionalnog kapaciteta bolesnika, zadržavanje neovisnosti u aktivnostima svakodnevnog života i samostalnog kretanja što je duže moguće te savjetovanje i poduka bolesnika i njegove obitelji za samostalnost i samozbrinjavanje unutar granica funkcionalnih mogućnosti. ${ }^{1}$

\section{Fizioterapijska procjena i intervencija osoba s mijastenijom gravis}

Fizioterapijski proces započinje procjenom pri kojoj se definira uzrok, posljedica funkcionalnog deficita i terapijski potencijal. Određuje se vrsta i razina oštećenja, funkcionalnog ograničenja i onesposobljenja te strategije fizioterapijske intervencije. ${ }^{19}$ Specifičnim mjernim testovima i instrumentima procjenjuju se problemi pacijenta s mijastenijom gravis i njihovo ograničavanje u životnim situacijama. Fizioterapijska intervencija kreira se u dogovoru s pacijentom, a u sklopu plana fizioterapije nalaze se informacije o tijeku bolesti, postavljaju se kratkoročni i dugoročni ciljevi tretmana te detalji fizioterapijske intervencije koja će se provoditi. ${ }^{20}$ Fizioterapijska procjena prema Međunarodnoj klasifikaciji funkcioniranja onesposobljenosti i zdravlja (International Classification Of Functioning Disability And Health - ICF) naglašava važnost u razini funkcioniranja poje- dinca i okoline. Okolina, osim prostora, podrazumijeva socijalna i psihološka obilježja bolesnikove okoline, dok se participacija promatra kroz uključenost i sudjelovanje u određenim životnim situacijama. ${ }^{21,22}$

Ciljevi su u fizioterapiji oboljelih od mijastenije gravis ublažavanje ili sprječavanje smanjenja funkcionalnog kapaciteta bolesnika, zadržavanje neovisnosti u aktivnostima svakodnevnog života te samostalnog kretanja što je duže moguće uz savjetovanje i edukaciju bolesni$\mathrm{ka}^{23}$ i njegove obitelji za samostalnost i samozbrinjavanje unutar granica funkcionalnih mogućnosti. Fizioterapijska intervencije kod osoba oboljelih od mijastenije gravis uključuje terapijske vježbe za snaženje mišića, ${ }^{24}$ terapijske vježbe za povećanje aerobnog kapaciteta, ${ }^{25}$ terapijske vježbe disanja, ${ }^{26,27,29}$ trening ravnoteže,${ }^{29}$ terapijske vježbe mobilnosti ${ }^{30}$ te terapijske vježbe za jačanje mišića zdjeličnog dna. ${ }^{31,32}$ Tjelesna aktivnost ključna je za poboljšanje simptoma i kvalitete života ${ }^{33}$ oboljelih od mijastenije gravis.

\section{Cilj istraživanja}

Cilj je ovog istraživanja ispitati funkcionalnost u aktivnostima svakodnevnog života oboljelih od mijastenije gravis s obzirom na spol, operaciju timusa i inkontinenciju te ispitati uključenost oboljelih u fizioterapijski proces i druge oblike tjelesne aktivnosti.

\section{Metode rada}

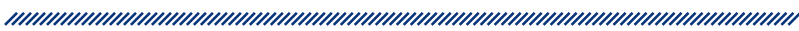

Podaci dobiveni upitnikom analizirani su programom IBM SPSS Statistics 23.0. Za statističku obradu podataka primijenjene su metode deskriptivne statistike aritmetička sredina, medijan, mod, raspon i standardna devijacija mjerenih varijabli. Od inferencijalne analize primijenjen je Levenov test kao preduvjet i t-test za nezavisne uzorke za provjeru statistički značajnih razlika u procjeni funkcioniranja u svakodnevnom životu osoba oboljelih od mijastenije gravis s obzirom na spol, timektomiju, inkontinenciju te uključenost u program fizioterapije. 


\begin{tabular}{|c|c|c|}
\hline \multicolumn{3}{|c|}{ Tablica 1. Osnovne karakteristike uzorka } \\
\hline & $\mathrm{Da}$ & $\mathrm{Ne}$ \\
\hline Timektomija & 122 & 89 \\
\hline Uključenost u FT & 27 & 184 \\
\hline Inkontinencija & 64 & 147 \\
\hline
\end{tabular}

\section{Uzorak ispitanika}

U istraživanju je sudjelovalo 211 ispitanika. Svi ispitanici imali su dijagnosticiranu mijasteniju gravis. Sudjelovalo je 181 žena (85,8 \%) te 30 muškaraca (14,2\%). Prosječna dob ispitanika u istraživanju bila je 39 godina, dok je dominanta vrijednost dobi iznosila 37 godina ( $D=37)$. Najmlađi ispitanik imao je 11 godina, a najstariji 76 godina (tablica 2). Većinski je broj sudionika ženskog spola. Globalno gledano, žene obolijevaju tri puta češće od muškaraca pa je i to mogući razlog manjeg broja ispitanika muškog spola. ${ }^{17}$ Prosječno trajanje bolesti ispitanika u godinama je 10,6 (+/-8,2) (tablica 2), a distribucija je pozitivno asimetrična. Timus su operirala $122(57,8 \%)$ ispitanika (tablica 1$)$.

\section{Instrumentarij}

Podaci su prikupljani putem online upitnika. Ispitivanje se provodilo tijekom lipnja i srpnja 2019. Za potrebe istraživanja kreiran je upitnik koji sastojao se od 18 pitanja. Sadržavao je opće podatke: dob, spol, zanimanje i trajanje bolesti u godinama. Pitanja su bila zatvorenog tipa, tri dihotomna pitanja te tri pitanja s višestrukim izborom, od kojih su dva pitanja imala mogućnost nadopune kako bi se prikupilo više informacija. Za procjenu funkcioniranja u svakodnevnom životu primijenjen je semantički diferencijal, ukupno sedam pitanja sa skalama od pet stupnjeva.

\section{Rezultati istraživanja i diskusija}

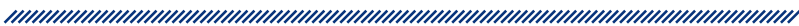

Odgovori ispitanika na pitanje o sadašnjoj uključenosti u program fizioterapije pokazuju da je uključeno samo $13 \%$ ispitanika, dok $87 \%$ ispitanika nije uključeno u fizioterapiju. U neki drugi oblik tjelesne aktivnosti većina ispitanika nije uključena (85,8 \%), a samo 30 ispitanika, odnosno $14,2 \%$, navodi da je uključeno u druge oblike tjelesne aktivnosti kao što su: teretana, vožnja bici- kla, fitness, pilates, joga i plivanje. Čak 184 ispitanika $(87,2 \%)$ nikad nije bilo uključeno u program fizioterapije zbog mijastenije gravis (tablica 1). Pozitivan stav o učinku fizioterapije i tjelesne aktivnosti na poboljšanje njihova zdravstvenog stanja ima 40,3\% ispitanika, dok in 59,7 \% smatra kako pogoršava, nema utjecaja ili nisu upoznati s učincima na zdravstveno stanje.

Rezultati ispitanika pokazuju da je najveći tjelesni problem ispitanika slabost ruku i nogu (26\%) te mišićni umor (26\%). Poteškoće u gutanju i govoru navodi $18 \%$ ispitanika, dvoslike $13 \%$ ispitanika, a spuštena očna vjeđa prisutna je kod $8 \%$ ispitanika. Pod ostalo $9 \%$ ispitanika navodi sve navedene probleme, poteškoće disanja, slabost mišića lica te slabost vrata i glave.

Rezultati ispitanika pokazali su da 64 (30,3\%) od 211 ispitanika ima problem povezan s inkontinencijom (tablica 1$)$.

Rezultati ispitanika povezani sa zadovoljstvom dostupnošću fizioterapije pokazali su da je čak 85 ispitanika (40,3\%) vrlo nezadovoljno dostupnošću fizioterapije, $12,3 \%$ ispitanika dostupnost fizioterapije ocijenilo je ocjenom 2, a $29,4 \%$ ispitanika ocjenom 3. $8,5 \%$ ispitanika dostupnost fizioterapije ocijenilo je ocjenom 4 , a samo 9,5 \% ispitanika ocjenom 5, odnosno ,jako zadovoljan".

Varijabla zadovoljstva funkcioniranja u svakodnevnom životu jednostavna je linearna kombinacija odgovora na tvrdnjama o kvaliteti kretanja, zadovoljstvu zdravstvenim stanjem, zadovoljstvu sposobnošću izvedbe aktivnosti svakodnevnog života, zadovoljstvu radnom sposobnošću, podršci koju dobivaju od prijatelja/obitelji, zadovoljstvu dostupnošću fizioterapije i učestalosti negativnih osjećaja, ocjenjivana je ocjenama od 1 do 5 , a rezultati su pokazali da je prosječan odgovor oko 3,3 do 3,97.

\begin{tabular}{l} 
Tablica 2. Osnovne deskriptivne vrijednosti \\
komponenti na online upitniku (n = 211) \\
\hline \\
\hline
\end{tabular}

S obzirom na normalnost distribucije varijable funkcioniranja u svakodnevnom životu, što je provjereno preko 
parametara asimetričnosti i spljoštenosti, u daljnjim analizama primijenjen je parametrijski test za ispitivanje razlika. Prije analize rezultata provjeren je preduvjet homogenosti varijance primjenom Levenova testa. S obzirom na to da nije značajan, bilo je opravdano primijeniti t-test za nezavisne uzorke. Značajnost je t-testa na $p>0,01$.

S obzirom na ciljeve istraživanja odnosno ispitivanja razlike funkcioniranja s obzirom na uključenost u fizioterapiju, na inkontinenciju, operaciju timusa i funkcioniranje u odnosu na spol, u obradi podataka primijenjen je Levenov test, odnosno t-test za nezavisne uzorke za ispitivanje statističkih značajnosti zadanih varijabli.

Odgovori ispitanika na pitanja o razlikama funkcioniranja u svakodnevnom životu s obzirom na dosadašnju uključenost u program fizioterapije zbog problema povezanih s mijastenijom gravis pokazali su da nema statistički značajnih razlika funkcioniranja u svakodnevnom životu s obzirom na uključenost u program fizioterapije $(p=0,26)$. Odgovori ispitanika na pitanja o razlikama funkcioniranja u svakodnevnom životu s obzirom na postojanje poteškoća povezanih s inkontinencijom pokazali su statističku značajnost $(p<0,01)$. Može se zaključiti da ispitanici koji imaju poteškoće povezane $\mathrm{s}$ inkontinencijom procjenjuju svoje funkcioniranje $\mathrm{u}$ svakodnevnom životu nižim u odnosu na ispitanike koji nemaju takvih tegoba. Također je dobivena statistički značajna razlika funkcioniranja u svakodnevnom životu s obzirom na operaciju timusa i ispitanika koji nisu imali operaciju timusa $(p<0,01)$. Rezultati spolnih razlika funkcioniranja u svakodnevnom životu pokazuju da nema značajnih statističkih razlika, odnosno može se pretpostaviti da su muškarci i žene podjednako zadovoljni funkcioniranjem u svakodnevnom životu $(p=0,42)$ (tablica 3). Levenov test pokazao je kako je moguće pretpostaviti homogenost varijanci između skupina.

Ovim istraživanjem željelo se provjeriti koliko su oboljeli od mijastenije gravis uključeni u fizioterapijski program i druge oblike tjelesne aktivnosti, utvrditi stav oboljelih o ulozi tjelesne aktivnosti na njihovu bolest te ispitati postoji li razlika funkcioniranja u svakodnevnom životu kod oboljelih s obzirom na poteškoće povezane s inkontinencijom, operaciju timusa i na spol.

Rezultati ovog istraživanja pokazali su da je samo $13 \%$ ispitanika bilo uključeno u fizioterapijski program, što opravdava izraženo nezadovoljstvo dostupnošću fizioterapije. U razlici funkcioniranja u svakodnevnom životu kod osoba koje su bile uključene u program fizioterapije i osoba koje nisu uključene u fizioterapiju nije nađena statistička značajnost, što može biti povezano s težinom bolesti i stanja ispitanika koji su bili uključeni u program fizioterapije te malim brojem ispitanika s težim motoričkim problemima. Rezultati ovog istraživanja u kontradikciji su s ostalim istraživanjima koja pokazuju da fizioterapija ima važnu ulogu u poboljšanju funkcioniranja u svakodnevnom životu. ${ }^{34}$ Rezultati ispitivanja razlika između muškog i ženskog spola u funkcioniranju u svakodnevnom životu oboljelih od mijastenije gravis pokazali su da s obzirom na spol nema statistički značajne razlike $u$ ispitivanim varijablama. Twork i suradnici (2010) u Dresdenu su proveli istraživanje na uzorku od 1518 ispitanika u kojem su se usmjerili na razlike među spolovima. Žene su u odnosu na muškarce niže ocijenile kvalitetu životu u fizičkom funkcioniranju, vitalnosti i mentalnom zdravlju. ${ }^{35}$

Rezultati ovog istraživanja pokazali su da je inkontinencija prisutna kod 30,3 \% ispitanika. Premda u istraživanju nije provjeravana vrsta inkontinencije, dobivena je značajna statistička razlika $(p<0,01)$, odnosno potvrđeno je slabije funkcioniranje u svakodnevnom životu osoba koje imaju inkontinenciju. Problemi povezani s urinarnom i fekalnom inkontinencijom mogu se javiti kod osoba oboljelih od mijastenije gravis. ${ }^{36}$ Sandler i suradnici (1998) prikazuju tri slučaja inkontinencije kod mijastenije gravis. Prvi je slučaj 31-godišnje žene kojoj je dijagnosticirana stresna urinarna inkontinencija $i$

\section{Tablica 3. Rezultati razlike funkcioniranja u svakodnevnom životu s obzirom na uključenost $\mathbf{u}$ fizioterapiju, poteškoće s mokrenjem, timektomiju i spol}

\begin{tabular}{|c|c|c|c|c|c|c|c|c|}
\hline & $t$ & $p$ & $S S$ & $\Delta \overline{\mathbf{x}}$ & SEM & NIP & VIP \\
\hline Uključenost u FT & $-1,11$ & 0,26 & 209 & $-1,27$ & 1,14 & $-3,53$ & 0,97 \\
\hline Inkontinencija & $-4,27$ & $<0,01$ & 209 & $-3,41$ & 0,79 & $-4,99$ & $-1,84$ \\
\hline Timektomija & 4,43 & $<0,01$ & 209 & 3,29 & 0,74 & 1,82 & 4,75 \\
\hline Spol & $-0,80$ & 0,42 & 209 & $-0,87$ & 1,09 & $-3,04$ & 1,28 \\
\hline
\end{tabular}


liječena je suspenzijom vrata mokraćnog mjehura otprilike osam mjeseci prije nego joj je dijagnosticirana mijastenija gravis. Kao uzrok inkontinencije ustvrđen je otvoren vrat mokraćnog mjehura, nemogućnost zadržavanja kontrakcije zdjeličnog dna i pretpostavljena hiperrefleksija koja se pojavila zajedno s pogoršanjem simptoma mijastenije. Drugi slučaj bio je stariji muškarac, koji se na početne simptome mijastenije žalio na urinarnu urgenciju i inkontinenciju, uz nekontrolirani flatus i povremenu fekalnu neugodnost kod kašlja ili kihanja. Otkriveno je da ima hiporefleksiju $m$. detrusora. Treći pacijent bila je mlada žena čiji su početni simptomi, uključujući i poremećaj inkontinencije, doveli do dijagnoze mijastenije, a na temelju procjene ustanovljeno je da ima akontraktilni mjehur. ${ }^{37}$ Zadovoljstvo radnom sposobnošću ispitanici su najčešće ocijenili ocjenom 3 u rasponu od 1 do 5 , što ukazuje na određene poteškoće pri izvođenju radne aktivnosti, što je u skladu s istraživanjem koje su proveli Nagane i suradnici (2017), koje je pokazalo da su oboljeli od mijastenije gravis bili žrtve diskriminacije. Sami ispitanici za navedene promjene na poslu naveli su predrasude, nedovoljnu kontrolu simptoma i dugotrajno liječenje. Umor je istaknut kao jedan od simptoma koji okolina može percipirati kao lijenost, a ne posljedicu bolesti. ${ }^{38}$ Promjene na timusu povezane su s mijastenijom gravis. Danas je timektomija indicirana za mlade bolesnike koji ne reagiraju na liječenje, prije svega u prvim godinama nakon dijagnoze.

$\mathrm{U}$ ovom istraživanju ispitivalo se koliko je osoba operiralo timus, a rezultati su pokazali da je $57,8 \%$ ispitanika uklonilo timus. Ispitano je postoje li razlike funkcioniranja u svakodnevnom životu s obzirom na to jesu li ispitanici operirali timus ili ne, a dobivene su statistički značajne razlike $(p<0,01)$. Ispitanici koji su operirali timus u prosjeku procjenjuju svoje funkcioniranje u svakodnevnom životu boljim u odnosu na ispitanike koji nisu imali operaciju. Rezultati ovog istraživanja u skladu su s drugim istraživanjima koja također pokazuju poboljšanje u funkcioniranju kod osoba koje su operirale timusnu žlijezdu. Španjolski istraživači u svojem su istraživanju zaključili da u mnogim slučajevima operacija stabilizira bolest, smanjuje lijekove i pojavu mijastenične krize, ali ta se korist ne pokazuje odmah nakon operacije, već progresivno nakon nekoliko mjeseci ili godina. ${ }^{8}$

Rezultati ispitivanja mišljenja o utjecaju tjelesne aktivnosti na mijasteniju gravis pokazali su da $40,3 \%$ ispitanika u ovom istraživanju smatra kako vježbanje i planirana tjelesna aktivnost poboljšavaju zdravstveno stanje, no samo ih je $14,2 \%$ trenutačno uključeno u nekakav oblik tjelesne aktivnosti, dok 83,4\% ispitanika trenutačno nije uključeno u program fizioterapije i drugi oblik tjelesne aktivnosti. 59,7\% ispitanika smatra kako planirana tjelesna aktivnost pogoršava, nema utjecaja ili nisu upoznati s učincima na zdravstveno stanje, što dovodi do mogućeg zaključka kako je razlog niske uključenosti u program fizioterapije i tjelesne aktivnosti slaba informiranost i educiranost. Wong i suradnici (2014) napominju kako je kod osoba oboljelih od mijastenije gravis zapažen sjedilački način života zbog mišićne slabosti i umora. ${ }^{29}$ O'Connor i suradnici (2019) u istraživanju navode kako većina osoba oboljelih od mijastenije gravis ispunjava preporuke vježbanja kroz razinu osnovne tjelesne aktivnosti, no dominira sjedilačko ponašanje. Razina aktivnosti mjerila se primjenom akcelerometra, koji se nosio u donjem dijelu leđa i mjerio je sedam dana zaredom količinu aktivnosti umjerene i snažne intenzivnosti, razinu tjelesne aktivnosti, broj koraka u danu i vrijeme sjedenja. Izmjerene vrijednosti korelirane su s trenutačnom težinom bolesti. Osobe oboljele od mijastenije gravis u prosjeku su $78 \%$ svojeg vremena provodile u sjedećim aktivnostima i dostigle prosječan broj od 7462 koraka dnevno. U usporedbi sa zdravom populacijom, osobe oboljele od mijastenije gravis manje su fizički aktivne. ${ }^{30}$

Neka od ograničenja ovog istraživanja povezana su s kategorizacijom osoba s generaliziranim i bulbarnim simptomima mijastenije gravis ili po klasifikaciji. Padua i suradnici (2001) dokazali su povezanost između težine bolesti i kvalitete života pojedinca. ${ }^{39}$ Predstavljeni rezultati otvaraju prostor za detaljnije istraživanje osoba s mijastenijom gravis. U budućim istraživanjima moglo bi se povećati uzorak ispitanika, klasificirati uzorak po motoričkim smetnjama, ispitati učinak umora na kvalitetu života, provjeriti socijalnu interakciju u odnosu na težinu bolesti te formalnu socijalnu podršku. Također bi se moglo specifičnije utvrditi razloge slabijeg funkcioniranja u svakodnevnom životu kroz detaljniju analizu čestica unutar pojedinih domena kvalitete života.

\section{Zaključak}

Neupitno je da mijastenija gravis s vremenom dovodi do smanjenja funkcioniranja u svakodnevnom životu. Ovo je istraživanje pokazalo da bolje funkcioniranje u svakodnevnom životu imaju osobe s operiranim timusom i osobe koje nemaju problem s inkontinencijom kao 
posljedicom mijastenije gravis. Također, istraživanje je pokazalo da je vrlo mali postotak osoba s mijastenijom gravis uključen u proces fizioterapije iako znanstveni dokazi upućuju da fizioterapija i tjelesna aktivnost imaju važnu ulogu u borbi protiv posljedica bolesti, funkcioniranja u svakodnevnom životu i povećanju kvalitete života oboljelih. Većina ispitanika ovog istraživanja smatra da planirana tjelesna aktivnost nema učinka na njihovo zdravlje. Slaba informiranost o benefitima fizioterapije i tjelesne aktivnosti može ukazivati na potrebu za većom edukacijom bolesnika. Edukacija i senzibilizacija javnosti o mijasteniji gravis i posljedicama koje uzrokuje nužna je pomoć u smislu boljeg razumijevanja problema oboljelih od mijastenije gravis.

\section{Referencije}

1. Kovač I. Rehabilitacija i fizikalna terapija bolesnika s neuromuskularnim bolestima. Zagreb; Savez Društava Distrofičara Hrvatske 2004.

2. Brinar V, Žagar M, Jurjević A. Neurologija za medicinare. Zagreb; Medicinska naklada, 2009.

3. Corrado B, Giardulli B, Costa M. Evidence-Based Practice in Rehabilitation of Myasthenia Gravis. A Systematic Review of the Literature. Journal of Functional Morphology and Kinesiology. 2020; 5 (4): 71.

4. Marsteller HB. The first American case of myasthenia gravis. Arch Neurol. 1988; 45 (2): 185-187.

5. Hughes T. The early history of myasthenia gravis. Neuromuscul Disord. 2005; 15 (12): 878-886.

6. Žagar M. Myasthenia gravis - bolest s mnogo lica. Zagreb; Medicinska naklada, 2018.

7. Alsop T, Williams K, Gomersall S. (2020). Physical Activity and Sedentary Behaviour In People With Myasthenia Gravis: A Cross-Sectional Study. https://assets.researchsquare.com/files/rs-113875/v1/8a8887bf-19ac-4b0eb996-f900c35f7692.pdf

8. Congregado M, Pinos N, Moreno-Merino S, Jimenez-Merchan R. Improvements in the Quality of Life of Patients with Myasthenia Gravis with Thymoma Who Underwent Video Thoracoscopic Thymectomy. Clin Surg. 2017; 2: 1318.

9. Nair AG, Patil-Chhablani P, Venkatramani DV, Gandhi RA. Ocular myasthenia gravis: a review. Indian journal of ophthalmology. 2014; 62 (10): 985-991.

10. Gilhus NE, Romi F, Hong Y, Skeie GO. Myasthenia gravis and infectious disease. Journal of neurology. 2018; 265 (6): 1251-1258
11. Burakgazi AZ, Richardson PK, Abu-Rub M. Dropped head syndrome due to neuromuscular disorders: Clinical manifestation and evaluation. Neurol Int. 2019; 11 (3): 8198.

12. Wendell LC, Levine JM. Myasthenic crisis. The Neurohospitalist. 2011; 1 (1): 16-22.

13. Thomas CE, Mayer SA, Gungor Y, Swarup R, Webster EA, Chang I, et al. Myasthenic crisis: clinical features, mortality, complications, and risk factors for prolonged intubation. Neurology. 1997; 48 (5): 1253-1260.

14. Chaudhuri A, Behan PO. Myasthenic crisis. QJM. 2009; 102 (2): 97-107.

15. Taraldsen Heldal A, Furlund Owe J, Gilhus NE, Romi F. Seropositive myasthenia gravis: a nationwide epidemiologic study. Neurology. 2009; 73 (2): 150-151.

16. Kulkantrakorn K, Jarungkiatkul W. Quality of life of myasthenia gravis patients. J Med Assoc Thai. 2010; 93 (10): 1167-1171.

17. Perković D, Stojčić Ž, Kiralj R. Istraživanje o kvaliteti života oboljelih od miastenije gravis u Republici Hrvatskoj Sestrinski glasnik 2014; 19 (3): 196-204.

18. Jevtić S. Kvaliteta života u oboljelih od miastenije gravis (Diplomski rad) Zagreb: Medicinski fakultet Sveučilišta u Zagrebu; 2018.

19. Klaić I, Jakuš L. Fizioterapijska procjena. Zagreb: Zdravstveno veleučilište; 2017.

20. Muppidi S. Outcome Measures in Myasthenia Gravis: Incorporation Into Clinical Practice. Journal of Clinical Neuromuscular Disease. 2017; 18 (3): 135-146.

21. Grozdek Čovčić G, Maček Z. Neurofacilitacijska fizioterapija. Zagreb: Zdravstveno veleučilište; 2011.

22. Grazio S. Međunarodna klasifikacija funkcioniranja, nesposobnosti i zdravlja (ICF) i reumatske bolesti. Reumatizam. 2010; 57 (2): 39-49.

23. Gazibara J. Kineziterapijski program za osobe oboljele od miastenije gravis. Zagreb, Medicinska naklada; 2002.

24. Laddu DR, Farr JN, Lee VR, Blew RM, Stump C, Houtkooper L, Lohman TG, Going SB. Muscle density predicts changes in bone density and strength: a prospective study in girls. J Musculoskelet Neuronal Interact. 2014; 14 (2): 195-204.

25. Westerberg E, Molin CJ, Lindblad I, Emtner M, Punga AR. Physical exercise in myasthenia gravis is safe and improves neuromuscular parameters and physical performance-based measures: A pilot study. Muscle Nerve. 2017; 56 (2): 207-214.

26. Fregonezi GA, Resqueti VR, Güell R, Pradas J, Casan P. Effects of 8-week, interval-based inspiratory muscle training and breathing retraining in patients with generalized myasthenia gravis. Chest. 2005; 128 (3): 1524-1530.

27. Rassler B, Hallebach G, Kalischewski P, Baumann I, Schauer J, Spengler CM. The effect of respiratory muscle endurance training in patients with myasthenia gravis. Neuromuscular Disorders. 2007; 17 (5): 385-391.

28. Calik-Kutukcu E, Salci Y, Karanfil E, Fil-Balkan A, Bekircan-Kurt CE,Armutlu K. Expiratory muscle strength as a predictor of functional exercise capacity in generalized 
myasthenia gravis. Neurosciences (Riyadh). 2019; 24(2): 95-100.

29. Wong SH, Nitz J, Williams K, Brauer S. Effects of balance strategy training in myasthenia gravis: a case study series. Muscle Nerve. 2014; 49 (5): 654-660.

30. O'Connor L, Westerberg E, Punga AR. Pattern of Habitual Physical Exercise in Myasthenia Gravis Patients. J Neuromuscul Dis. 2019; 6 (1): 85-91.

31. Reitz, A, Fisang C, Müller SC. Neuromuskuläre Funktionsstörungen des unteren Harntraktes jenseits von Querschnittlähmung und multipler Sklerose. Der Urologe. 2008; 47: 1097.

32. Filipec M, Jadanec M, Zudenigo D, Sučić M, Ovčariček S. Inkontinencija - stop! Zagreb: Hrvatski zbor fizioterapeuta; 2014.

33. Cass S. Myasthenia Gravis and Sports Participation. Head, Neck, and Spine. 2013; (12): 1: 1821.

34. Salci $Y$, Karanfil E, Balkan AF, Kütükçü EÇ, Ceren AN, Ayvat F, Bekircan-Kurt CE, Armutlu K. Functional exercise capacity evaluated by timed walk tests in myasthenia gravis. Muscle Nerve. 2019; 59 (2): 208-212.
35. Twork S, Wiesmeth S, Klewer J, Pohlau D, Kugler J. Quality of life and life circumstances in German myasthenia gravis patients. Health Qual Life Outcomes. 2010; 8:129.

36. Ratto C, Doglietto GB, (ur.). Fecal Incontinence: Diagnosis and Treatment. Milan; Springer; 2007.

37. Sandler PM, Avillo C, Kaplan SA. Detrusor Areflexia in a Patient with Myasthenia Gravis. Int J Urol. 1998; 5: 188190.

38. Nagane $\mathrm{Y}$, Murai H, Imai T, Yamamoto D, Tsuda E, Minami $\mathrm{N}$, et al. Social disadvantages associated with myasthenia gravis and its treatment: a multicentre crosssectional study. BMJ Open. 2017; 7 (2): e013278.

39. Padua L, Evoli A, Aprile I, Caliandro P, Mazza S, Padua R, et al. Health-related quality of life in patients with myasthenia gravis and the relationship between patientoriented assessment and conventional measurements. Neurol Sci. 2001; 22 (5): 363-369. 


\section{INVOLVEMENT OF MYASTHENIA GRAVIS PATIENTS IN PHYSIOTHERAPY AND PHYSICAL ACTIVITIES}

\author{
1 Marija Marinović \\ 1 Mirjana Telebuh \\ 2 Iva Lončarić Kelečić \\ 1 Gordana Grozdek Čovčić \\ 3 Želimir Bertić \\ 1 Mihaela Grubišić \\ 1 University of Applied Health Sciences, Zagreb \\ 2 Department of Rehabilitation and Orthopaedic Aids, \\ University Hospital Centre, Zagreb \\ 3 Institute of Public Health of Bjelovar-Bilogora County
}

\section{Summary}

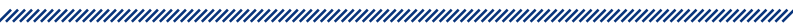

Myasthenia gravis is an autoimmune neuromuscular disease in which organism produces antibodies against receptors located on muscle cells thus preventing transmission of stimuli from nerves to muscles. Muscles tire rapidly and muscle weakness occurs. The aim of this study was to examine the functionality in the daily life of patients with myasthenia gravis related to gender, thymus surgery and incontinence, and to examine the involvement of patients in the physiotherapy process and other forms of physical activity.

211 subjects diagnosed with myasthenia gravis were included in the research - 181 women $(85.8 \%)$ and 30 men $(14.2 \%)$ with the mean age of 39 years. Results of this research show that most subjects believe that planned physical activity aggravates their health status, does not affect it, or they are not aware of the effects it has on their health; they are less physically active and most do not undergo a physiotherapy treatment or do other physical activity. A statistically significant difference in functioning in daily life was established in subjects who had undergone a thymectomy $(p<0.00)$ and those with incontinence problems $(p<0.00)$. Myasthenia gravis undoubtedly leads to a poorer functioning in daily life and educating myasthenia gravis patients on the importance of therapeutic exercise brings about benefits such as improving their functioning in activities of daily living (ADL).

Keywords: myasthenia gravis, physiotherapy, therapeutic exercise, incontinence, functioning in daily life. 